\title{
Decentralisation in Uganda: Prospects for Improved Service Delivery
}

\author{
Roberts Kabeba Muriisa*
}

\begin{abstract}
Since the 1980s, many Sub-Saharan African countries have been undergoing structural reforms with a view to promoting efficient service delivery. Decentralisation, defined as the transfer of authority from central to local governments to perform certain duties, is seen as one of the public sector reform strategies to increase service delivery. Decentralisation in Uganda began in 1986 with the coming into power of the National Resistance Movement, which aimed at promoting democracy and enhancing local participation. In Uganda, political decentralisation developed along with financial decentralisation. The goal of political decentralisation was to promote people's participation in the democratic process of Uganda. This took the form of Administrative Units - Resistance Councils (RC) ${ }^{1}$ running from the village to district levels. Financial decentralisation, on the other hand, attempted to assign responsibilities and taxes between the centre and local governments, to enable the transfer of grants and other resources to different parts of the country, and to improve service delivery. This paper will review different government, public and academic documents as well as findings of other researches such as UN reports about decentralisation and service delivery in Uganda. Based on these sources the paper will answer the following questions: to what extent does decentralisation increase service delivery? To what extent does decentralisation increase efficiency, participation, accountability and effectiveness? What are the challenges of implementing decentralisation in Uganda?
\end{abstract}

Key words: Decentralisation, accountability, efficiency, economy, effectiveness and performance.

\section{Résumé}

Depuis les années 1980, de nombreux pays d'Afrique subsaharienne ont connu des réformes structurelles visant à promouvoir une fourniture de services

* Faculty of Development Studies, Mbarara University of Science and Technology, Uganda; e-mail Muriisak@gmail.com. 
efficiente. La décentralisation, définie comme le transfert d'autorité du gouvernement central aux administrations locales pour l'accomplissent de certaines fonctions, est considérée comme l'une des stratégies de réforme du secteur public pour améliorer la fourniture de services. La décentralisation, en Ouganda, a commencé en 1986 avec l'arrivée au pouvoir du Mouvement National de Resistance, qui visait à promouvoir la démocratie et à renforcer la participation locale. En Ouganda, la politique de décentralisation s'est développée en même temps que la décentralisation financière. L'objectif de la décentralisation politique était de promouvoir la participation populaire dans le processus démocratique de l'Ouganda. Cela a pris la forme d'unités administratives - les Conseils de la Résistance (CR) ${ }^{1}$ qui assuraient la direction locale depuis le village jusqu'au niveau du district. La décentralisation financière, d'autre part, a tenté d'attribuer des responsabilités et des impôts entre le niveau central et les gouvernements locaux, pour permettre le transfert des subventions et d'autres ressources aux différentes régions du pays et améliorer la fourniture des services. Ce document passera en revue différents documents gouvernementaux et publics, des documents académiques et les conclusions d'autres recherches tels les rapports de l'ONU sur la décentralisation et la fourniture de services en Ouganda. Sur la base de ces sources, cet article répondra aux questions suivantes: dans quelle mesure la décentralisation améliore-t-elle la fourniture de services? Dans quelle mesure la décentralisation améliore-t-elle l'efficience, la participation, la responsabilisation et l'efficacité? Quels sont les défis de la mise en œuvre de la décentralisation en Ouganda?

Mots clés: décentralisation, responsabilisation, efficience, économie, efficacité et performance.

\section{Introduction}

Decentralisation is the transfer of administrative and political powers from central to regional or sub-national governments. Decentralisation is a longtime practice in Africa. However, it became more pronounced in the 1980s and 1990s when it featured as one of the World Bank's structural criteria. Decentralisation programmes in Africa followed the recommendations of the World Bank for developing countries to devolve political and administrative powers to local and autonomous levels. The reason for this focus is that most of the social services such as health, education, water and sanitation that are a responsibility of government are systematically failing (World Bank, 2003). The adjustment programme, therefore, had improved and more efficient distribution of goods and services as its prime target. In addition, the recommendation was made on the basis that decentralisation would quicken decision-making processes and increase participation by the local people. This would result in decisions better tailored to people's needs and reduced corruption and clientelism, which went along with centralised government. 
Proponents of decentralisation argue that the ills of centralised government include corruption, clientelism and political alienation and that these can be cured by decentralisation of power from central government to sub-national governments (Faguet 2000).

The motivation for decentralisation varies from country to country and from region to region. In Eastern Europe and the former Soviet Union, it was part of political transformation from centralised government where few participated in decision-making to a decentralised system where many could participate in the decision-making process. In Sri Lanka and South Africa it was a response to ethnic and regional conflicts. It is argued that decentralisation provides an institutional mechanism for bringing divided groups into a formal, rule-bound bargaining process (Treismann, 1998). Decentralisation thus serves as a path to national unity. In Uganda, Chile and Cote D'Ivoire, it was carried out for improving service delivery (Shah and Theresa 2004). In Uganda, the Local Government Act (1997), a central part of the decentralisation policy, stipulates that most central government powers and responsibilities for public services planning and delivery should be devolved to local governments.

The aim of this paper is to discuss decentralisation as a policy for delivering services in Uganda. The arguments for decentralisation are reviewed against its success in improving service delivery in Uganda. The paper examines the different decentralisation frameworks and their implication for service delivery. It goes on to examine the challenges of decentralisation and proposes mechanisms that can make decentralisation an effective tool for delivering services to local communities. Government and public documents, academic analysis and findings of other research about decentralisation and service delivery in Uganda are considered. Based on these sources the paper will answer the following question: To what extent has decentralisation increased service delivery in Uganda? In this respect, the extent to which decentralisation has increased efficiency, participation, accountability and effectiveness in the service sector in Uganda will be analysed. Finally, the paper will discuss the challenges of implementing decentralisation in Uganda.

\section{What is Decentralisation?}

Definitions of decentralisation are many but four types predominate: (1) deconcentration - the transfer of administrative responsibilities from the central government to local governments within a central government ministry or agency; (2) delegation - the transfer of managerial and administrative responsibilities of central ministries for specifically defined functions to organisations that are external to the regular bureaucratic structure; (3) devolution - the substantial transfer of powers and authority and functions from 
higher or central government to local units, upon which the local units or governments subsequently acquire significant and autonomous financial and legal powers to function without reference to central government; (4) privatisation - the transfer of responsibilities to private or individual companies in a process by which service delivery is made by private companies who win tenders through a competitive tendering process administered by the government agency.

The Ugandan Ministry of Finance, Planning and Economic Development (MFPED) argues that devolution features prominently in Uganda (MFPED, 1998). One of the main features of devolution is the ability of local governments to exercise both financial and political autonomy. This paper will illustrate that decisions at local government are frequently influenced and/or affected by the financial and political dependence of local governments on the central government. This feature eliminates devolution as a decentralisation practice in Uganda. A close look at the implementation of the decentralisation policy indicates that the decentralisation system in Uganda can well be described as a mixture of delegation, deconcentration and privatisation. Most of the public services are currently being offered by private firms who through competitive bidding are awarded tenders to provide services.

\section{Aims of Decentralisation}

Decentralisation in most developing countries arose in the 1970s out of the dissatisfaction with the centralised systems of national planning and administration that were the by-products of former colonial systems. These systems had been emphasised in the 1950s and the 1960s during the struggle for independence. The 1970s saw a need to involve more people in the planning and decision-making process, and to direct planning to people's needs. In the 1990s the World Bank regarded decentralisation as a necessary part of structural reform to promote efficient use of resources and to address local needs of developing countries. Thus, Golola (2003:256) argues that 'the process of decentralisation in sub-Saharan Africa has coincided, and perhaps even dictated by, efforts by the donor community to reorient aid policies'. Apart from these internal and external donor pressures for countries to decentralise, globalisation played a major role in the decentralisation movement. Decentralisation comes as a response to the global demand for equity, accountability and efficient service delivery. Decentralisation is opposed to centralised government systems, which had minimal responsiveness to local needs.

It is argued, therefore, that decentralisation makes possible speedier and more responsive public service attuned to local or individual needs. It enhances 
efficiency, through reduced bureaucracy (Pollit, Birchall and Putnam 1998:1). Muriisa (2007), argues that decentralisation offers two main benefits to the people; freedom to access and freedom to decide. The former implies that decentralisation enables people to voice their needs and to access certain resources through their representatives. The later implies that within a decentralised framework, people take autonomous decisions without influence from the central government. According to Turner and Hulme (1997), through delegation within organisations and coordination between organisations, improved decision-making and greater efficiency and effectiveness are promoted. According to Braun and Grote (2000), participatory local governments are more responsive to local needs, elected officials are more accountable and responsive to the people than officials of central governments, and people are more involved in decision-making.

Golola (2003:259) presents four main objectives of decentralisation, and all have improved service delivery as their main component: (1) to transfer real power to the districts and therefore to reduce the workload of officials at the centre; (2) to bring administrative and political control to the point where services are delivered; (3) to improve financial accountability through establishment of clear links between tax payment and service provision; and (4) to improve the capacity of local councils to plan, finance and manage the delivery of services to their constituencies.

Hutchinson (1991) reviews a number of country experiences with decentralisation. In Mexico, decentralisation was seen as strengthening operational efficiency and management of health services at the level of state governments and to link planning of the health services more closely to overall national planning of the country. In Papua New Guinea, decentralisation was a method of creating regional autonomy with a view to increasing appropriate responses to local needs and quicker decision-making. In Tanzania, decentralisation aimed at increasing participation of the people in planning and improving coordination between the relevant agencies, reducing duplication of services and making more effective use of the available resources. In South Africa, decentralisation was employed as a means of redressing past inequities created by the apartheid regime.

Kayizzi-Mugerwa (1998:36) argues that the main objectives of decentralisation in Uganda are increased democracy, accountability and responsiveness, and the improved capacity of the local people to participate in the decision-making process, especially with regard to service delivery, and to promote local ownership of the programmes.

Faguet (2000) shows that in Papua New Guinea devolution increased popular participation in government and improved the planning, management 
and coordination capacity of provincial administrators. In Senegal and New Zealand, it attempted to bring services nearer to people.

\section{Measuring the Achievements of Decentralisation}

In the discussion above, I have pointed out that decentralisation aims at addressing people's needs at the grassroots. It has to be added, however, that decentralisation is still ongoing in many countries, and therefore it is not easy to establish its successes or failures. Despite this limitation there are measures one can use to identify levels of achievement, namely, efficiency, economy, effectiveness, performance and accountability.

Efficiency: According to proponents of decentralisation, it promotes efficient allocation of resources. Efficiency measures the extent to which output is maximised using minimum resource inputs. Two types of efficiency may be considered: allocative efficiency, which considers a match between public service and local needs, and productive efficiency, which considers a match between provision of the public service and its costs, improved accountability and reduced levels of red tape.

Economy: This refers to the production using the cheapest means. In competitive tendering, it is assumed that resource inputs are obtained from the cheapest source while services are provided by the lowest bidder.

Effectiveness: This measures the extent to which the original objectives and policy goals are achieved.

It has to be emphasised that the above measures are not isolated from each other but rather affect and impinge on each other. For example, increased economy may be achieved with loss of effectiveness and efficiency. Thus an increase in school enrolment without a corresponding increase in recruitment of teachers may lead to loss of effectiveness because some children may lack sufficient attention.

Accountability: With regard to decentralisation, accountability concerns the one to whom the officials account. There are two forms of accountability: political accountability in which the elected representatives account to their electorates, and administrative accountability, or the extent to which managers and leaders achieve set targets. Usually, the focus is on the extent to which targets are achieved within the limits of the budget. Both accountability types are applicable.

\section{Decentralisation and Service Delivery in Uganda}

Decentralisation in Uganda is taking place alongside broad economic and political reforms and should be seen in the context of these fundamental reforms. Uganda's 1995 constitution and 1997 Local Government Act specify 
five levels of local government - district, county, sub-county, parish and village, among which the 78 districts and more than 900 sub-counties $^{2}$ have political authority and financial autonomy. Each of the decentralisation efforts (political and financial) had specific goals of improving service delivery.

Financial decentralisation is expected to facilitate access to resources by the local governments. The financial decentralisation involves devolving budgetary and spending powers to the districts. Important expenditure responsibilities in the social sector were devolved to its sub-national governments (Nsibambi 1998). The goal of political decentralisation was to involve more people in the decision-making and planning processes to respond to local needs. The LCs are consultative forums for local decision-making (Saito 1999). Through elected representatives, policy proposals are channelled to the legislative bodies. Within the LC framework, all districts are expected to compile district development plans, which must reflect grassroots needs. The LCV is the council in which development plans of the district are made. The LCs are supposed to implement the development plans such as provision of public services. Within the LC framework, extension workers to implement the development plans are employed at the LC3 level. The public service officials (local administrators) report to local council officials, who in turn account to the people, not to the central government as was the case in the former centralised system. This accountability procedure is reflective of the democratic process in service provision in Uganda. Saito (1999) traces the planning process in the districts of Kampala, Rakai and Mukono, and argues that the planning process and accountability procedures reflect popular participation in initiating and implementing development programmes.

The goal of financial decentralisation was to transfer authority for collecting and allocating taxes and other financial grants to local governments. The provision, management and maintenance of primary healthcare, primary education, roads and basic urban services were decentralised to districts. In spite of decentralisation, however, some important decisions and responsibilities remained at the centre. For example, in health, staffing decisions are made at the district level but district funding comes largely from the central government in the form of conditional grants with explicitly identified uses. In education the curriculum and most funding for primary education flow from the centre but decisions about personnel, school construction and operational maintenance are made locally (World Bank 2001). In Uganda, the provision of primary education serves as a good example in which participation of the people in the delivery of services is exhibited. Parents and the local population provide labour for the construction of classrooms while government provides funding for corrugated iron sheets and other capital inputs. 
In health, the immunisation programme shows a marked success through decentralisation. Nsibambi (1998) points out that in Bushenyi district, the District Three Year Development Plan, 2001-2004 indicated that district service coverage of immunisation was 80 per cent. This programme succeeded largely because of the involvement and participation of local leaders in mobilising local people. The local council officials, especially the local council secretary for women and health, were instrumental in mobilising people to take children for immunisation.

Through competitive tendering road maintenance has improved. Many rural and feeder roads are maintained. However, there are complaints that many private bodies do not pay employees the going rate for their labour. The poor pay structure has not only led to low motivation for workers but also is reflected in the shoddy work provided by some private contractors. These contractors use poor materials in road-building, resulting in constructed roads deteriorating quickly.

\section{Failures and Challenges of Decentralisation as Policy for Improving Service Delivery in Uganda}

Despite the few identified examples of successful service delivery in Uganda resulting from decentralisation, there still remains a gap between service provision and local needs. This gap is created by lack of adequate funding at the local level, and is largely reflected in the education and health sectors. In the education sector, since the inception of the Universal Primary Education (UPE) programme in 1997, there has been a growing number of enrolled children in schools. This increase, however, has not been met by corresponding increase in both infrastructure and staffing. As a result, overcrowding and low staffing remain major challenges that hinder proper implementation of the programme in some districts.

With the introduction of universal primary education in 1996, school enrolment rose from 3.6 million students to 6.9 million between 1996 and 2001 (UNDP 2004). Yet this near-doubling in school enrolment was not matched by staff recruitment owing to lack of adequate finance from central government and local sources. Most financial allocations to local governments are either put to non-education expenditures or do not reach their final destination:

In 1996 a public expenditure tracking survey of local governments and primary schools revealed that only $13 \%$ of the per-student capitation grants made it to the schools in 1991-1995. In 1995 for every dollar spent on non-wage education items by the central government, only 20 cents reached the schools, with local governments capturing most of the funding (UNDP 2004:63). 
In health, provision of medical care and services has fallen far short of local needs through lack of finances. A survey of health services conducted in 1996 found that the most common problem facing the health sector was that no drugs were being provided to patients. This was because most of the grants transferred to districts for health had been used for salaries (Nsibambi 1998:58). In addition, the lower tiers of government lacked the ability to manage public finances and maintain proper accounting procedures. Spending on primary healthcare halved, from 33 per cent to 16 per cent, during decentralisation (Akin, Hutchinson and Strumpf 2001).

It should be noted that for decentralisation to achieve its targets, there has to be high level of public accountability. A number of problems with regard to accountability have been registered. There was lack of transparency in the allocation of resources and weak budgetary procedures with regard to record-keeping and auditing. In education, for example, there was disproportionate distribution of finance to the schools, with the poor schools receiving less or nothing of the capitation grants. Parents and students had little or no information regarding the amount of the capitation grant entitled to them.

Kayizzi-Mugerwa (1999:42) argues that the success of decentralisation will depend on the capacity of districts and urban governments to raise their own revenue and use it efficiently in the provision of services. However, the generation of local revenues is limited, with local governments largely depending on central government financial transfers. In the 1990s, on average, only 13.2 per cent of revenue in Uganda could be generated locally (Saito 1999). A national graduated tax had been operational for many years until 2006. With the introduction of decentralisation, many districts started to charge education, environment and sanitation, and health taxes along with graduated tax. These additional charges specifically targeting certain service sectors substantially contributed to the service delivery in these sectors. Graduated tax, however, was removed in 2006, leaving these districts financially paralysed.

The abolition of the Graduated Personal Tax (GPT) meant that the local and urban governments had limited financial sources to finance public services, as is the case with education and health cited above. As a result there has been an increase in the reliance by local governments on central government. This lack of financial autonomy affects the implementation of development plans and consequently limited service delivery since most of funds are diverted before they reach their final destination.

The Ministry of Finance, Planning and Economic Developmentsurvey on health and agricultural service delivery in Uganda (1998) found that there was deficiency in the percolation of funds allocated to these sectors. Despite the bid for financial autonomy implied by decentralisation, the central 
government still provided funding for major services at local government level. However, provision of funding suffered diversion in the process of allocation to local governments. MFPED and MAFAI (1998) thus reported a shortage of incentives and facilitation for districts. This resulted in the inability to deliver Agricultural Extension Services (AES) to grassroots farmers. Analysis of most district budget estimates for the 1997/1998 financial year showed that only 1 per cent of the total expenditure was allocated to AES.

It should be pointed out that the most daunting challenge facing decentralisation as a framework for service delivery is a lack of capacity and personnel at sub-national government level to exercise responsibility for service delivery. The lower-level governments lacked the ability to manage public finances and maintain proper accounting procedures. As a result, lower levels of funding reached the local level.

The lack of funding at the local level paralysed the personnel sector. In the first instance, decentralisation led to staff retrenchment through civil service reform. In the agricultural sector the Agricultural Extension officerfarmer ratio was 1:1000-3000 in 1998. The wider area covered by each extension officer meant that few farmers had access to these services. On average, the proportion of farmers contacting Agricultural Extension Officer was only 10 per cent. In Tororo district, AE staffs were deployed only up to sub-county level and had limited direct contact with farmers. In Bushenyi, Muriisa (2001) found that whereas extension workers had motorcycles to use to visit farmers, they only had a monthly allocation of 25 litres of fuel for extension work. Only 1 per cent of farmers were receiving extension services.

The same problems of shortfalls in funding and personnel were observed in health, with limited medical personnel and medicine, and in education with limited teaching staff. Spending on public health, as earlier mentioned, fell from 33 per cent to 16 per cent during decentralisation (Akin, Hutchinson, and Strumpf 2001), while, as also noted, increased enrolment of primary school children during UPE resulted in overcrowding and low staff capacity to handle large classes. The increase in school enrolment was not marched by increased recruitment of new staff (UNDP 2004).

Another challenge of decentralisation to improved service delivery is the perception gap between service receivers and providers about the benefits of the policy. According to Saito (1999), on the one hand, the public service officials perceive that decentralisation improves control and the mobilisation of resources, and on the other, the service receivers perceive that services have not improved in recent years. 
Further, decentralisation as an approach to service delivery is limited by the failure of politicians to cede political power to the local governments. Golola (2003) maintains that politicians at the centre have little wish to cede power to the local governments. They propose reforms including decentralisation when they expect benefit for themselves. This failure to cede power by politicians at the centre limits democracy and autonomous decision-making at the local level.

One of the objectives of decentralisation is

to transfer real power to the district and thus reduce the load on the 'remote' and under-resourced central government officials. These officers are often remote in terms of geographical distance and frequently unknown to the local people in terms of language, culture, interests and values (Murembe, Mokhawa and Sebudubudu 2005).

Further, implementation of the decentralisation programme is marred by the conflicts between the politicians and the civil servants. Largely, conflicts emerge from the demand for accountability by the civil servants from the politicians. In several districts, there have been conflicts between the Local Council Five (LCV) chairman and the Residence District Commissioner, ${ }^{3}$ for example, Ntungamo and Kiruhura districts. In the Daily Monitor for 20 August 2007, it was reported that the Ntungamo RDC claimed to be under threat from the LCV chairman because he demanded accountability and had exposed the LCV chairman's corruption practices. In Kiruhura, the acting RDC reportedly resigned, citing corruption and intimidation from elected representatives.

Another limitation of the decentralisation policy comes from the response to externally determined programmes that differ from local needs. In one district, residents argued that funds to implement decentralisation were usually obtained from donors who fund specific projects even when these may not be priorities of the local area. In the district, members cited an example of a road recently constructed in the area, but pointed out that if they were given a choice, they would have preferred equipping the health centres with medicine.

In terms of accountability, the lack of financial autonomy and insufficient funds to facilitate local government officials means that many of the local government officials including councillors have remained voluntary, without compensation. Such people are difficult to hold accountable to the local communities (Golola 2003). There is increased corruption by these officials who try to compensate themselves by misappropriating funds and by extortion from the citizens. In the decentralised framework, I can rightly assert that there is decentralisation of corruption. This is a big challenge to service 
delivery because much of the available financial resources end up enriching individuals employed in the public sector, particularly local governments.

\section{Conclusions}

This paper has discussed decentralisation as an approach to service delivery in Uganda. The paper argues that decentralisation was aimed at addressing local needs that were not being addressed by the centralised framework. The paper reviews different academic and empirical works done in Uganda since decentralisation policy was started. The paper premises that for proper evaluation of the extent to which decentralisation has led to the improvement of service delivery, one needs to look at accountability, efficiency and effectiveness as tools of evaluation. The paper argues that decentralisation has achieved only a limited success in service delivery in the education and health sectors where the participation of citizens was suggested as a main contribution of decentralisation.

The paper shows that, despite the good intentions of decentralisation, its implementation has faced challenges of financing, personnel capacity at the local level and effective monitoring of service delivery. The paper concludes that as a policy for improving service delivery, decentralisation falls short of realising that objective in Uganda, despite a few isolated examples of successful service delivery, as in the case of immunisation, education and participatory planning. Despite the challenges of decentralisation, which are discussed as hindering effective service delivery in Uganda, in consideration of the benefits of decentralisation, the paper concludes that if such challenges could be addressed, decentralisation has more potential of improving service delivery than centralised government.

The paper suggests that improving local funding sources and creating mechanisms through which public officials could be held more accountable would lead to improved service delivery. Attaining financial capacity would lead to effective implementation of decentralisation and efficient service delivery.

\section{Notes}

1. Representation to the council was by popular election by the citizens. After the 1995 constitution, the RCs were replaced by Local Councils (LCs) but the system remained the same.

2. The number of districts and sub-counties has increased substantially with some counties attaining district status and new ones being created.

3. The LCV chairman is an elected politician who heads the district while the $\mathrm{RDC}$ is the presidential appointee to the district and head of public service in the district. 


\section{References}

Akin, J., Hutchinson, P. and Strumpf, K., 2001, 'Decentralisation and Government Provision of Public Goods: The Public Health Sector in Uganda', in Abt. Associates: MEASURE Evaluation Project Working Paper 01-35, Bethesda, MD.

Braun, Von Joachim and Grote, Ulrike, 2000, 'Does Decentralisation Serve the Poor?' Paper read at IMF Conference on Fiscal Decentralisation, Washington, DC, 20-21 November.

Faguet, J.-P., 2000, 'Decentralisation and Local Government Performance: Improving Public Service Provision in Bolivia’, in Revista De Economia De la Universidad Del Rosario III.

Golola, L. M., 2003, 'Decentralisation, Local Bureaucracies and Service Delivery in Uganda', in Reforming Africa's Institutions, ed. Kayizzi-Mugerwa, S., New York: United Nations University Press.

Hutchinson, P. 1, 1991, Health Care in Uganda, WDP 404, World Bank Discussion Paper, Washington: World Bank.

Kayizzi-Mugerwa, S., 1998, Uganda Towards Result-oriented Economic Management, Country Economic Report, Stockholm: Swedish International Development Agency (SIDA).

Kayizzi-Mugerwa, S., 1999, Uganda at the End of the 1990s: A Medium-term Assessment, Stockhlom: Swedish International Development Agency (SIDA). MFPED, 1998, Vision 2025: Prosperous People, Harmonious Nations, Beautiful Country: A Strategic Framework for National Development, Vol. 2, Background Papers, Kampala: Ministry of Finance, Planning and Economic Development.

MFPED and MAFAI, 1998, Government of Uganda, Statement to the December 1998 Consultative Group Meeting, Paper read at Towards A Sector-wide Approach, Developing a Framework for the Modernisation of Agriculture, Kampala.

Murembe, N., Mokhawa, G and Sebudubudu, D., 2005, Decentralisation and African developmental states: Experiences from Uganda and Botswana, in The Potentiality of Developmental States in Africa, ed. P. Mbabazi and I. Taylor, Dakar: Codesria.

Muriisa, Roberts, 2001, NGOs and Rural Development in Uganda, MPhil thesis, monograph, University of Bergen, Norway.

Muriisa, Roberts, 2007, The AIDS Pandemic in Uganda: Social Capital and the Role of NGOs in Alleviating HIV/AIDS Challenges, PhD thesis, Public Administration and Organisation Theory, Bergen, Norway.

Nsibambi, Apollo, 1998, Decentralisation and Civil Society in Uganda: The Quest for Good Governance, Kampala: Fountain.

Pollitt, Christopher, Birchall, Johnston and Putnam, Keith, 1998, Decentralising Public Service Management, London: Macmillan.

Saito, Fumihiko, 1999, Decentralisation in Uganda: Challenges for the 21st Century, Copenhagen: DANIDA. 
Shah, Anwar and Theresa, Thompson, 2004, Implementing Decentralized Local Governance: 'Treacherous Roads with Potholes, Detours and Road Closures', in Policy Research Working Papers, Washington, DC: World Bank.

Turner, Mark and Hulme, David, 1997, Governance, Administration and Development: Making the State Work, New York: Palgrave.

UNDP, 2004, World Development Report, Washington, DC: United Nations.

World Bank, 2001, Decentralization and Governance: Does Decentralization Improve Service Delivery?, in Prem Notes.

World Bank, 2003, World Development Report 2004: Making Services Work for Poor People, Washington, DC: World Bank and Oxford University Press. 